\title{
Local Purchase in the Bamyan Emergency Operation
}

\section{Background}

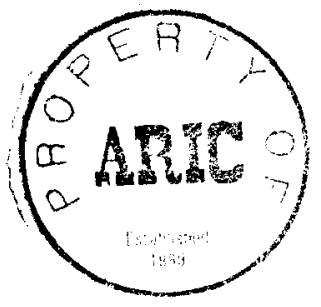

Bamyan Province is part of a larger, multi-province ethnic, political, and geographic area called the Hazarajat. The Hazarajat consists of all of Bamyan and parts of b) Eastern Ghor, c) Northeast Uruzgan. d) Southeast Jawzian, e) Southern Samangan, f) Southwest Baghlan, g) Northwest Ghazni and h) Northwest Wardak. The region consists of 14 districts scattered in valleys over a mountainous terrain with peaks more than $3,500 \%$ meters above sea level. On the south, southwest and southeast the Hazarajat is surrounded by areas under the contrnl of the Talihan. On the north, northwest and northeast, the region is bordered by areas under the control of various factions of the northern alliance.

In this mountainous and isolated region, the population is concentrated in narrow valleys. The more populous towns are linked by a network of very poor unpaved roads, while many settlements are accessible by tracks traversable only by horse, by donkey or on foot. All of the populated areas are at high altitudes, with Bamyan district in Bamyan province at an elevation of over 2500 meters. The climate is therefore severe. Access from outside the borders is not possible during the winter except from the north through Pulikhumri; many areas become inaccessible by road from mid-December until the end of April.

The population of Hazarajai region is roughly estimated at 1.2 million. It is peopled predominately by the Hazara people, who are ethnically distinct from their northern neighbors the Uzbeks and Taiiks and very distinct from the Pashtoons in the south. In Sunni Afghanistan, the estimated 1.1 Hazaras are mainly of the Shia sect of Islam and are thus a religious minority with traditionally close links to Shia Iran in the west.

\section{The Bamyan Economy}

Banyan has a pre-industrial agricultural economy which is highly dependent on only a handful of crops. It relies on exporting potatoes, livestock and livestock products. dry fruits and handicrafts to neighboring provinces. Income from the sale of these items in normal years is utilized to meet people"s food needs during winter. In good years. the inhabitants hunker down for the winter and just barely manage to survive until the snow melts and access to the outside world becomes possible again. As a chronic food deficit area, the region depends heavily on food "imports" - especially cereals--from Ghazni and Kabul financed by the export of potatoes and livestock.

The situation in Bamyan deteriorated in 1997 due to a combination of factors. First. the strict blockade of the Ghazni/Kabul trade route drastically reduced access to traditional markets for cash crops, which in turn resulted in an unmarketable oversupply of potatoes and livestock, low prices and a reduction in household income. On the other hand, the blockade affected availability of wheat and other imported food stocks on the local 
market, whichmeant that prices rose dramatically. Second, food production declined because of excessive rains, floods in early spring, frost and early snow. Finally, although WFP normally provides about 3,000 tons in food aid to the province each year, this was not possible in 1997. Throughout the year, the north of the country remained either highly insecure or subjest to actual fighting. WFP's efforts to get food in from the north did not work. In addition. in September/October 1997 all WFP food stocks from Mazar and Hairatan were looted, with more than 3000 tons of food stolen.

By August 1997, it was becoming clear that the situation in Bamyan was worsening. WFP, the UN and donors all negotiated with the Taliban extensively - and ultimately to no avail-- to allow access for the delivery of humanitarian food aid into Bamyan through blockaded areas Simultanenusly, WFP explored a range of other options to provide Bamyan with food assistance. These included the following:

- From WFP stocks

--Supply via Pakistan-Ghazni from the south, ruled out due to the blockade. fighting.

--Supply from Torghundi via Turkmenistan from the west, ruled out due to

--Supply through Ghor, ruled out due to the blockade.

--Supply from Mazar. impossible due to insecurity and looting of food.

- Regional purchase: Kazakstan-Termez-Hairatan-Mazar-Bamyan. This was undertaken, but various factors including insecurity and late arrival hindered the delivery of this food.

- Local purchase

--of the surplus potato crop from farmers in the area

--of surplus wheat outside the region and transported into the area.

- Airlift

--from Peshawar

--from Termez.

Most of these options did not prove feasible, while other options required extended negotiations and high costs (such as an airlift). WFP therefore relied heavily on local purchase of surplus food to reach the targeted population before the closure of mountain passes due to heavy snowfall. An airlift which was eventually begun proved of very limited utility, since it had to be discontinued after just over two weeks when the Taliban began bombing Bamyan airstrip.

\section{The Emergency Operation}

In early November 1997 WFP launched a needs assessment mission in the region to determine the extent of vulnerability and identify the directly and severely affected population as well as to suggest modalities of assistance. The mission confirmed the vulnerability of the population and recommended food assistance to almost 160.000 people who might be at risk of starvation during the latter part of the winter.

In order to get the operation under way, given the imminence of winter and the lack of 
availability of internationally donated food aid, WFP instituted a vigorous campaign for local purchase. (For full details on the financial side of the operation, see Appendix 1: "Analysis of Consolidated Bamyan Yakawlang EMOP Expenditures for the Period 01.11.97-19.03.98." Transpot costs of this local purchase opeation will be accounted for separately.)

\section{Local Purchase of Surplus Potatoes}

Potato purchase was conducted on a much larger scale than the purchase of wheat because thousands of tons of surplus potatoes (a cash crop) existed on the local market due to the biochade. Beginning in early November, a local purchase committee for potatoes was formed, consisting of uf to three international WFP staff members, one WFP national staff, one national NGO representative, and one representative of the local authorities. Given the existence of the large surnlus in the area, the committee decided to

\begin{tabular}{|l|}
\hline \multicolumn{1}{|c|}{ Summary } \\
Loca: Purchase \\
- Potatoes: 5,317 tons \\
- Wheat: 516 tons \\
Beneficiary Coverage \\
- 131,000 persons \\
\hline
\end{tabular}
identify: small and medium scale farmers willing to part with a portion of their stored harvest. The direct purchase from the producers themselves not only allowed WFP to mobilize large quantities of food for the needy, but it also gave much needed cash income to the farmers. For identification, a committee of WFP, NGOs. community leaders, and local authorities traveled around Bamyan. Yakawlang, and Wardak - the surplus areas-to register farmers willing to sell. In total, 1,078 farmers reached an agreement with WFP. Once the farmers were registered, the purchasing team weighed and inspected the quality of the potatoes and the availability of household reserves. They then issued a contract in duplicate, one for the farmer to use in dispatching and thereafter obtaining payment from the WFP office. and one for the UFP accountant s records to verify farmers" claims. WFP next issued to the farmers empty bags marked "WFP". These were not available in the areas and were supplied by WFP from Peshawar and Kabul. Subsequently the WFP logistics team collected the bagged potatoes on the basis of the purchase contracts, and distribution teams were responsible for distributing them to the targeted beneficiaries. Farmers traveled to Bamyan and Yakawlang to collect their payments from three international finance personnel from the Country Office who were stationed there. In the case of Wardak, where 664 tons of potatoes were purchased, farmers came to the temporar. WFP base there to collect their payments from WFP staff. (See Appendix 2 for purchase details and Appendix 3 for sample contracts.)

In addition to the direct purchase operation. WFP identified 169 tons of potatoes in Wardak for which WFP could not furnish cash resources. These potatoes were purchased on credit in a deal that allowed the farmers to swap potatoes for wheat in a 2:1 ratio (taking into consideration the market price and the cost of transport) with the wheat to be picked up in Bamyan City.

The market price of potatoes at the beginning of this operation was determined to be $\$ 78 /$ ton, which was the equivalent of approximately 4,285,714 Mazar afghanis ( 


\section{4.}

2,013,024 Kabul afghanis) per ton. This price remained constant during the entire potato buying operation in all locations. In total, WFP purchased 5,148 tons of potatoes locally in Bamyan, Yakawlang, Wardak, and Panjao districts at a cost of just over $\$ 408,000$. Inclujing the 169 tons of potatoes swapped for wheat, local procurement came to a total of $5 . \$ 17$ tons.

\section{Local Purchase of Wheat}

Hight priority was identification of any available surplus wheat in either the Hazarajat or surrounding areas. In mid--iovember, a mission comprised of one international WFP staf: one national WFP staff, one international NGO staff member, and one representative from the local authority succeeded in identifying 400 tons of local wheat in neighboring Baghlan Province, a traditional surplus area. In this case, the mission formed a purchasing committee and identified four traders with a surplus of wheat who were willing to sell to WFP. The contract drawn up specified an amount of up to 400 tons of wheat at $\$ 428 /$ ton ( $C \& F$ ), which included relatively high transport costs to Bamyan City due to the high insecurity of the routes. Eventually, WFP succeeded in purchasing 416 tons of this wheat. (See Appendix 4 for details about this transaction.)

While Baghlan is a surplus area, most of the Hazarajat is not. WFP monitored the price of wheat in the local markets in towns such as Bamyan City, lakawlang, Panjao and Waras. The markets were so small, and supplies of wheat so limited, that the decision was made to avoid local purchase in these areas, which would have disrupted the local market. However, in December, the local purchase committee in Yakawlang (comprised of tiree UFP international staff, one WFP national staff, one national representative from an international NGO, and one representative of the local authorities) identified 200 tons of surplus wheat in Lal district of Ghor Province, which had been imported from Samangan Province. This was one of the affected areas of the Hazarajat targeted for assistance by WFP. Local authorities in Lal and the joint WFP-OXFAM assessment team in Lal all agreed that this purchase would not disrupt the local market conditions, because residents of the area lacked the purchasing power to buy the wheat. Therefore, a representative of wheat seliers in Lal was nominated in the presence of the local shuras and the purchasing commitee. The wheat was purchased at the price of $\$ 279 /$ ton $-\mathrm{C} \mathrm{\&} \mathrm{F}$ La:--(687.933,000 Kabul afghanis), which was the price in the local market at the time of purchase. The contract issued specified all terms and conditions of the agreement. For this quantity, coupons and records were maintained. The wheat was subsequently distributed to the earlier identified beneficiaries within Lal district. In total only 100 tons of the 200 tons identified could be purchased because deteriorating weather necessitated the withdrawal of the EMOP team. (Refer to Appendices 5 and 6 for details about this transaction.) The Lal wheat was purchased at a lower rate than the Pulikhumri wheat because it did not include transport costs and was distributed within Lal district itself. The Pulikhumri wheat was inclusive of transport costs from Pulikhumri to Bamyan City over routes which were highly insecure at the time.

In total, WFP succeeded in identifying and purchasing 516 tons of wheat locally. As part of their duties, WFP staff were monitoring the market prices of various 
commodities, and especially of potatoes and wheat. It was evident that WFP's local purchase had not disturbed or negatively affected the market. In addition, the intervention also enabled farmers to buy available wheat in the market. In other words, WFP injected cash (which normally comes from export) and stimulated market forces to a certain extent. 


Description

Transportation

Potatoes

Wheat

Non food items

Fuel for transportation

\section{Purchase of potatoes}

Purchased in Bamyan

Purchased in Yakawlang

Purchasec by Hazel in Panjao

Purchased by Ali in Wardak

\section{Puchase of Wheat}

Purchase in Pulikhumri/Bamyan

Purchase in Lal

\section{Operational cost}

Wages

Rent of building

Vehicle maint. \& fuel

Miscellaneous.

Other payments

Advances

Loan repayment

Total Payments

Airift expenditure see annexure ' $A$ '

\section{Total expenditure}

Transportation \& other Payables annexure "B"

Total expenditure including payables

Note

5

6

7

$: 2$
$: 3$

M.T.

US S

Mazar Afs.

Kabul Afs.

Equivalent USS

\%age

\begin{tabular}{|c|c|}
\hline 352,961 & $7.714,648.540$ \\
\hline 123,413 & $3.715,833.7 \cong 2$ \\
\hline 3,645 & $5,218.020$ \\
\hline 100,500 & $1.419,875.000$ \\
\hline 580,519 & $12.855,575.332$ \\
\hline
\end{tabular}

$\begin{array}{r}2,024,043,362 \\ 63,367,000 \\ 17,000,000 \\ - \\ \hline 2,104,410,362\end{array}$

$\begin{array}{r}567,862 \\ 191,650 \\ 4,396 \\ 125,636 \\ \hline 889,645\end{array}$

\begin{tabular}{r|}
\hline 33.98 \\
11.47 \\
0.26 \\
7.52 \\
\hline 53.23
\end{tabular}

\begin{tabular}{|c|c|c|c|c|c|}
\hline $2,277.04$ & - & $4.032,000.000$ & $2,863,380,000$ & 182.329 & 10.91 \\
\hline $2,201.48$ & 143,036 & $1.526,164, \angle 50$ & $18,750,000$ & 170,780 & 10.22 \\
\hline 4.91 & $=$ & - & $10,515,000$ & 407 & 0.02 \\
\hline 664.60 & 31,500 & - & $602,604,973$ & 54.850 & 3.28 \\
\hline $5,148.03$ & 174,536 & $5,558,164<50$ & $3,495,249,973$ & 408,366 & 24.44 \\
\hline
\end{tabular}

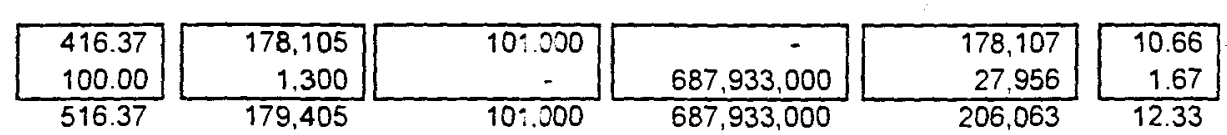

\begin{tabular}{|c|c|c|c|c|c|}
\hline 8 & 1,000 & $1,337,51 \mathrm{C} .100$ & $246,648,000$ & 34,234 & 2.05 \\
\hline g & 1,800 & - & $=$ & 1,800 & 0.11 \\
\hline 10 & 7.037 & $949.88=.500$ & $46,105,000$ & 25,639 & 1.53 \\
\hline 11 & 5,460 & 978.795 .504 & $240,031,000$ & 32.088 & 1.92 \\
\hline & 15,297 & $3,266,18: 104$ & $532,784,000$ & 93,762 & 5.61 \\
\hline
\end{tabular}
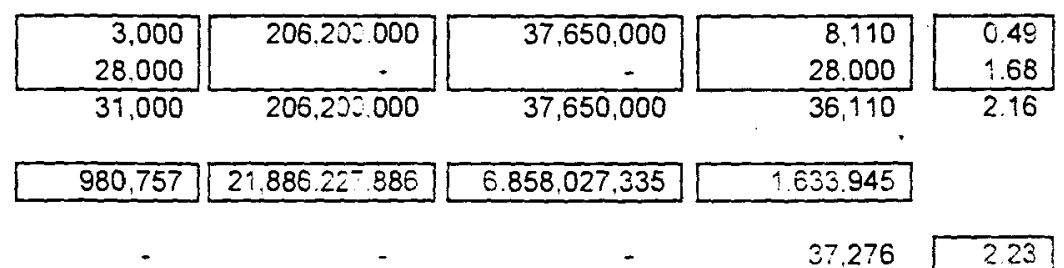

37.276

223

$=\frac{980.757}{21.886 .221 .886} \frac{-6.858 .027 .335}{1.181 .720 .000}=\frac{1.671 .221}{21.486}=\frac{100.00}{.}$

\section{$980.757 \quad 23.067 .547 .886] 6.858 .027 .335 \quad 3.692 .707$}

Note: This summary analysis should be read in conjunction with the annexed notes to the accounts The summary analysis reflect the consolidated figures of Bamyan \& Yakawlang. Average market rates of exchange, US $\$ 1=$ Mazar Afs. 56.487 \& US $\$ 1$ = Kabul Afs 25.808 have'een applied for US dollars equivalent figures.

Compiled \& Consolidated by: Zulfiqar Ali

$$
\begin{aligned}
(4) & = \\
& =710398
\end{aligned}
$$$$
\perp
$$

Reviewed by: Helmut W. Rauch

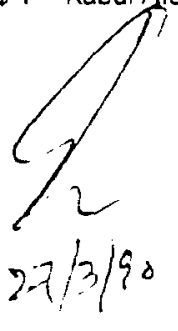

Faisal Siddiai

$$
f . \text { Sidair }
$$




\section{WFP Country Office Afghanistan \\ Analysis of airlift expenditure for WFP Bamyan Emergency Operation 97/001/BAM}

2. Office Equipment / Office Supplies

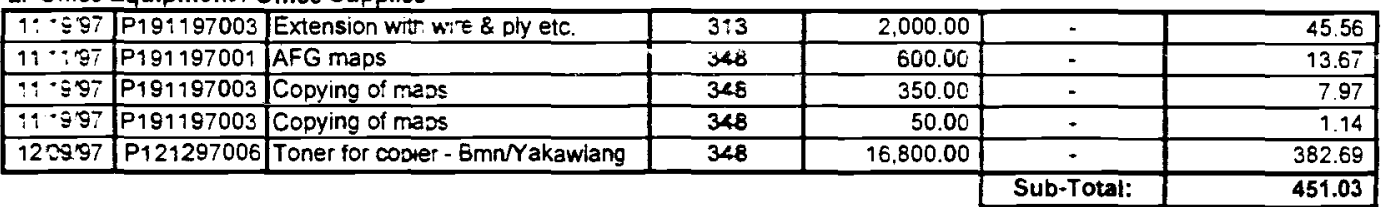

3. Communications

3. Communications
\begin{tabular}{|l|l|l|l|l|l|r|}
\hline & & & & & \\
\hline $12: 107$ & $1 / 12$ & Battery for Cosar- Base & 509 & $2,287.00$ & - & 52.10 \\
\hline
\end{tabular}

4. Miscellaneous Expenditure

\begin{tabular}{|c|c|c|c|c|c|c|}
\hline $19 \cdot 9197$ & P191197001 & Sleeping bags & $6: 9$ & 7.800 .00 & - & 177.68 \\
\hline $9 i \div: 97$ & P191197002 & 5 rolls film & 6.9 & 450.00 & - & 10.25 \\
\hline $11 \div: 197$ & $P 191197002$ & Sleeping bags & 679 & 2.600 .00 & - & 59.23 \\
\hline$: 9 \cdot: 297$ & P191197002 & Printing process $0^{x}$ film & 679 & 516.00 & - & 11.75 \\
\hline $9: \div 2 / 97$ & P191197002 & Various items & $\epsilon \cdot 9$ & 5.100 .00 & - & 116.17 \\
\hline $11: 9197$ & P191197002 & Immediate reourement for mission & 679 & 2.800 .00 & - & 63.78 \\
\hline $91: 7 / 97$ & P191197002 & Immediate reoure hent for mission & 679 & $9.625 .0 \mathrm{C}$ & 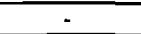 & 37.02 \\
\hline $41+9 / 97$ & $P 191197002$ & Purchase of reliet rems & $E \div 9$ & $12,768.00$ & - & 290.84 \\
\hline$: \div: 8 / 97$ & $P 191197003$ & Batteries for came $a$ for Bmn missi. & $6-9$ & 253.00 & - & 5.76 \\
\hline $9: 999$ & P191197003 & Enlarging of pho:es & 6.9 & $1,350.00$ & - & 30.75 \\
\hline$\because ;: 9 / 97$ & P191197003 & 1 roll fitm \& Dassojn copies & 679 & 90.00 & - & 2.05 \\
\hline$\because 9997$ & P19:197003 & Plastic cove: \& taming of pictures & $6^{-9} 9$ & 700.00 & - & 15.95 \\
\hline $9 \cdot 9 \cdot 9 / 97$ & $\mathrm{P} 191197003$ & Printing prosess $c^{t}$ film & 6.8 & 729.00 & - & 16.67 \\
\hline $1127 / 97$ & P191197003 & Emacy supdies to Bmn Operation & $6-9$ & 50.814 .00 & - & $1,157.49$ \\
\hline$\div 208: 97$ & $9: 12$ & Printing process of film & $6^{-9}$ & 639.00 & - & $14.5 €$ \\
\hline$i 2109 / 97$ & $111 / 12$ & Emgcy supdies to $\mathrm{Bmn}$ Operation & $6: 9$ & $\uparrow 2.982 .00$ & - & 295.72 \\
\hline$\$ 2,15 / 97$ & $25 / 12$ & Printing Drocess $e^{c}$ film & $6 \neg 9$ & 241.00 & - & 5.49 \\
\hline$: 224 / 97$ & $1 / 12$ & AFG visa fee of $\varepsilon$ Journalists & $6-9$ & - & - & 180.00 \\
\hline :2/01/97 & P191297001 & Battery for cooar & 6.9 & $2,287.0 \mathrm{C}$ & - & 52.10 \\
\hline $12 / 31 / 97$ & P191297012 & Maps printing of Films & 679 & 1.415 .00 & - & 32.23 \\
\hline $01: 43 / 98$ & P190198001 & Spares & $6-9$ & 2.370 .00 & - & 53.99 \\
\hline $01 / 19 / 98$ & $P 190198006$ & Metal box. Daper zarton & 679 & 900.00 & - & 20.50 \\
\hline $01: 21 / 98$ & P190198011 & Repair of codan & $6: 9$ & 5.750 .00 & - & 130.98 \\
\hline C2/47/98 & $P 190298010$ & cost of measuring tape & 6.9 & 400.00 & - & 9.11 \\
\hline $03: 03 / 98$ & P190398006 & Printing of film & $\epsilon^{-\Xi}$ & 415.00 & 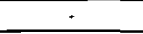 & 945 \\
\hline$: 2: 23: 97$ & $P 121297021$ & Snow chains & $E-9$ & 20.500 .00 & - & $46699^{-}$ \\
\hline $01 / 26 / 98$ & $P ; 20198027$ & Misc Airlift expenses & 679 & 99.901 .00 & - & 2.275 .65 \\
\hline $03 / 05 / 98$ & - & Misc Airlift exper.ses in process & 6.9 & $594,079.30$ & - & $13,532.56$ \\
\hline $12 / 13 / 97$ & $\mathrm{P} 111297028$ & Advance to Angus Fraser & 679 & $\cdot$ & - & 15.000 .00 \\
\hline $01 / 13 / 98$ & $P 0198005$ & PSO Oil Company & 679 & - & - & 2.354 .57 \\
\hline & & & & & \multicolumn{2}{|l|}{ Sub-Total: } \\
\hline
\end{tabular}

5. LTSH Expenditure

5. LTSH Expenditure
\begin{tabular}{|c|c|l|r|r|r|r|}
\hline $11 / 25 / 97$ & P191497003 Weighino scales & 77 & 3.500 .00 & - & 79.73 \\
\hline $12 / 04 / 97$ & $5 ! 12$ & Ration Cards & 777 & 1.500 .00 & - & 34.17 \\
\hline $12 / 09 / 97$ & P121297005 & Emgcy ration caras for Yakawlang & 777 & 10.000 .00 & - & 227.79 \\
\hline $12 / 12 / 97$ & $21 / 12$ & Purchase of 20m rope for packing & 777 & 80.00 & - & 1.82 \\
\hline
\end{tabular}




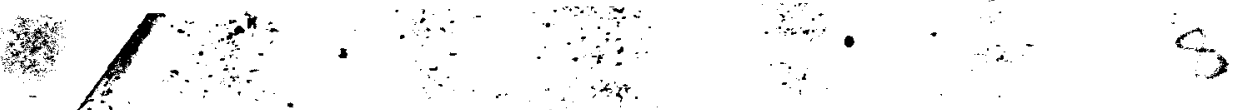

WDAL FOOD PROGRAMANE - AFGHAISTAN

\section{BAMYNAN}

REOUIRED WFOOUATON FOR COUPLETION OF BAUYYA ACCOUNTS

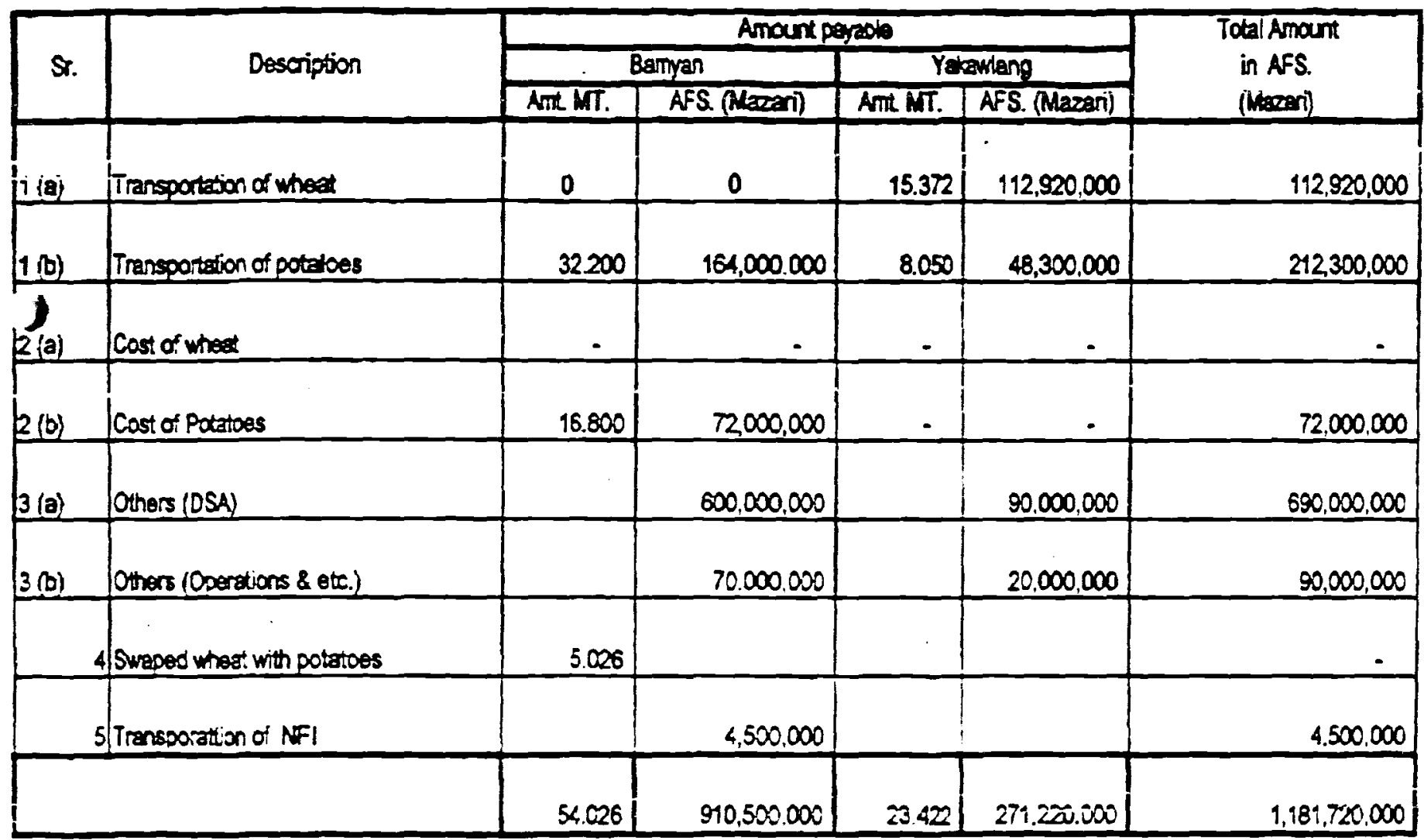

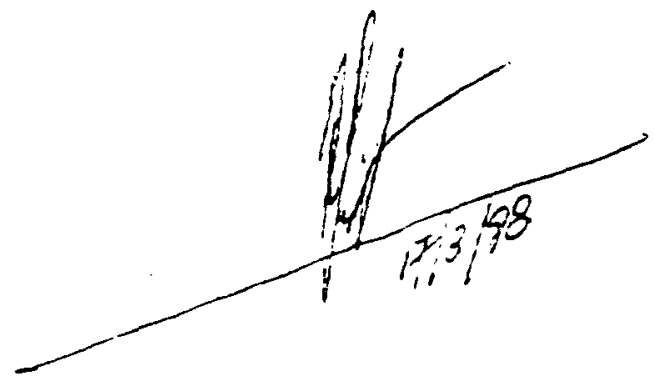




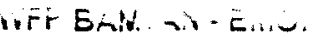

CONSOLDATED BAMYAN-YAKAWLANG RECEIPT \& PAYMENT ACCOUNT FOR THE PERIOD 01.11.97 TO 19.03.98

Description

Note US \$ 1 Mazar Afs. Kabul Afs. Equivalent US\$

RECEIPTS:

Opening talance 01.11.97

1

$94.856,624$

1,679

Receipts fom C.O.

US \$ exctanged into local currency

Kabuli excrianged into Mazari

Total cast received from C.O.

2

\begin{tabular}{|c|r|r|r|}
\hline $1,900,000$ & $200.000,000$ \\
$(565,923)$ & $\begin{array}{r}974,037,500 \\
19,782.120,300 \\
297.840,000 \\
6,059,290,000 \\
(186,150,000)\end{array}$ \\
\hline $1,334,077$ & $20,279.960,300$ & $6,847,177,500$ & $1,958,408$ \\
\hline $1,958,408$
\end{tabular}

Loan receved

$4,0001,530.500,000$

$7.169,000$

$2,700,000$

31.0995

Receipts. Transfers \& refunds

$(350,000)$

232

Cash retuned to C.O.

988,077

$21,912485,924$

$6,849,877,500$

$(350,000)$

Total cast: available

$\underline{988,077} 21,912485,924$

PAYMENTS:

Transporation

5

\begin{tabular}{|r|r|r|}
\hline 580,519 & $12,855.575,332$ & $2,104,410,362$ \\
\hline 174,536 & $5,558.164,450$ \\
179,405 & 101,000 \\
\hline 353,941 & $5,558,265,450$ & $3,495,249,973$ \\
$687,933,000$ \\
$4,183,182,973$
\end{tabular}

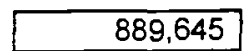

Purchase of potatoes

Puchase of Wheat

6

7

Operational cost

Wages

\begin{tabular}{|r|r|}
\hline 1,000 \\
1,800 \\
7,037 \\
5,460 \\
$1,337,510,100$ \\
- \\
$949.880,500$ \\
$978.796,504$ \\
\hline 15,297 & $3,266.187,104$ \\
\hline
\end{tabular}

$246,648,000$
$46,105,000$
$240,031,000$
$532,784,000$

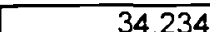

Rent of buiiding

Vehicle maint. \& fuel

Miscellaneous.

$$
\begin{gathered}
8 \\
9 \\
10 \\
11
\end{gathered}
$$

\section{Advances}

$$
12
$$

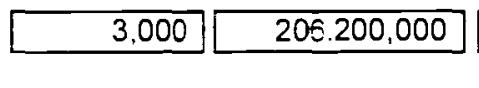

$37,650,000$

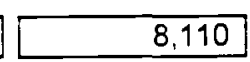

Loan repayment

13
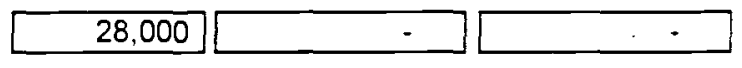

\begin{tabular}{|c|c|c|}
\hline 980.757 & $21,886.227,886$ & $6,858,027,335$ \\
\hline 7,320 & $26,258.038$ & $(8.149 .835)$ \\
\hline
\end{tabular}

28,000

Total Payments

Balance

14

$1,633,944$

Note: These accounts should be read in conjunction with the annexed notes to the accounts.

The accounts reflect the consolidated figures of Bamyan \& Yakawlang.

Average market rates of exchange, US $\$ 1=$ Mazar Afs. 56,487 \& US $\$ 1=$ Kabul Afs 25,808 have'een applied for US dollars equivalent figures.

Compiled \& Consolidated by:

Zulfiqar Ali

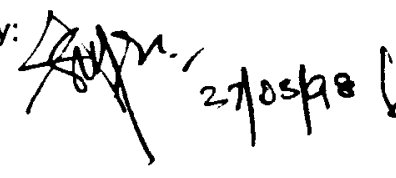

Reviewed by:

Helmut W. Rauch
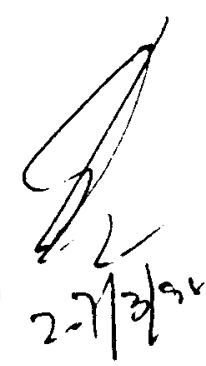

Faisal Siddiqi

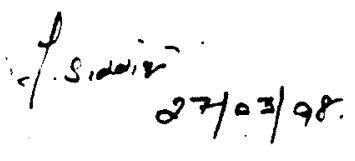


WFP BAMYAN - EMOP

NOTES TO THE CONSOLIDATED BAMYAN-YAKAWLANG RECEIPT \& PAYMENT ACCOUNT FOR THE PERIOD FROM PERHD 01.11.97 TO 19.03.98.

\section{Opening balance.}

Yakawlang Afs. Imprest account shows the opening balance as on November 01. 1997

2. Receipts from Country office

date
$04 / 11 / 97$
$10 / 11 / 97$
$17 / 11 / 97$
$24 / 11 / 97$
$28 / 11 / 97$
$02 / 12 / 97$
$13 / 12 / 97$
$16 / 12 / 97$
$17 / 12 / 97$
$18 / 12 / 97$
$20 / 12 / 97$
$24 / 12 / 97$
$21 / 01 / 98$
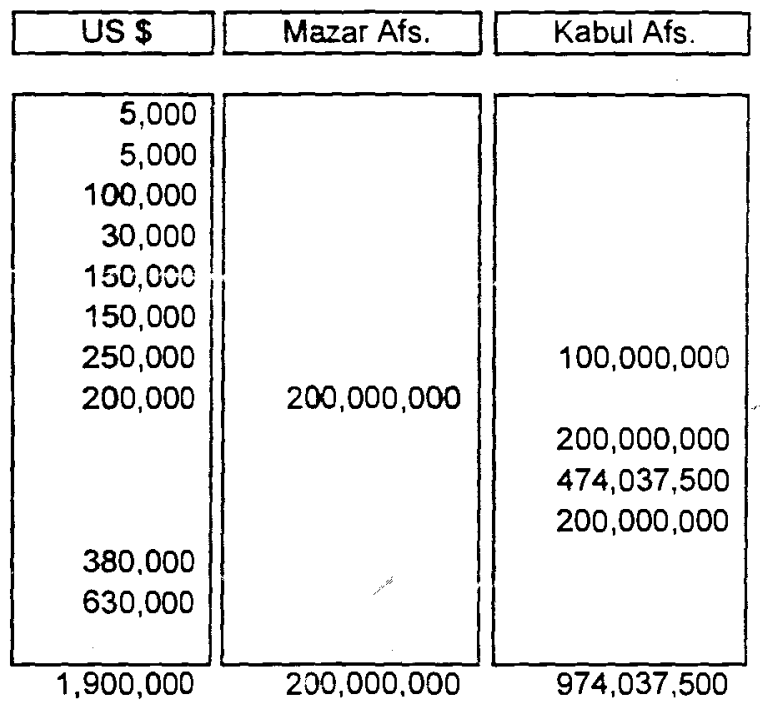

Equivalent US\$

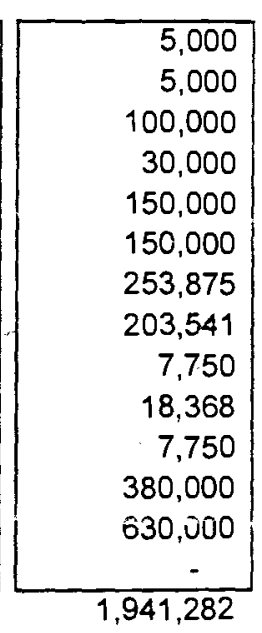

3. US dollars exchanged into local currency.

Exchanged in Bamyan

Exchanged in Yakawlang

Exchanged by Mr. Hazel in Panjac \& Waras

Exchanged by Mr. Asif in Lal

Exchanged by Mr. Ali in Panjao \& Waras
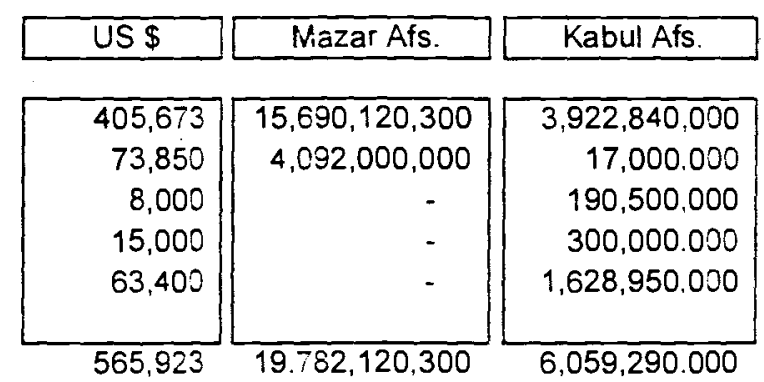

Equivalent US\$

565,923

$19.782,120,300$

$6,059,290.000$

$\begin{array}{r}\hline 429,766 \\ 73,100 \\ 7,381 \\ 11,624 \\ 63,118 \\ \hline 584,990\end{array}$

4. Loan received for payments.

Received in Yakawlang

Received in Yakawlang

Received in Yakawlang

Received in Bamyan date

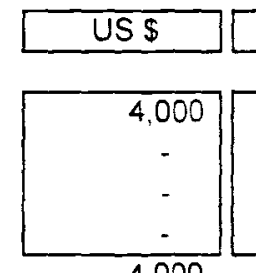

Mazar Afs.

$236,500,000$

$114,000,000$

$180,000.000$

$03 / 01 / 98$

$09 / 01 / 98$

$20 / 01 / 98$
$1,000,000,000$

$1,530,500,000$

Kabul Afs.

Equivalent USS
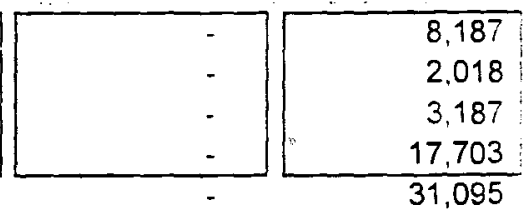
5. Transportation. -

\section{- Transportation of Potatoes}

From Bamyan to - Yak

From Bamıan to -Yak *

From Bam!an to -Panjao

From Bamyan to -Waras

From Bamyan to -Waras*

From Bamyan to -Sarab*

From Bamyan to -Shebarto

From Yak to -Lal

From Yak to -Panjao

From Yak to -Waras

From Yak to -Yak

From Yak to *

From Panjao to -Waras

Paid in Panjao, Wardak by Ali for transponation of potatoes

\section{- Transportation of Wheat}

From Bamyan to - Yak

From Bamyan to -Yak*

From Hariton to -Bamyan

From PIK to TLBF \& BMN

From Yak to -Panjao

From Yak to -Waras

From Yak to *

From Panjao to -Waras

From Lal to various places

- Transportation of non food items

Jute bags from Yak to -Siahkak

Pick up from Panjao -Yak

Paid in Panj.\& Waras by Hazel

- Fuel for trucks

Grand total

\begin{tabular}{|r|}
\hline M.T. \\
\hline 123.12 \\
27.30 \\
49.00 \\
$1,604.00$ \\
387.10 \\
70.00 \\
285.55 \\
368.78 \\
670.02 \\
248.29 \\
655.61 \\
358.91 \\
31.31 \\
\\
664.60 \\
\hline 5.543 .59
\end{tabular}

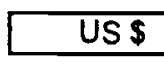

Mazar Afs.

Kabul Afs.

Equivalent US\$
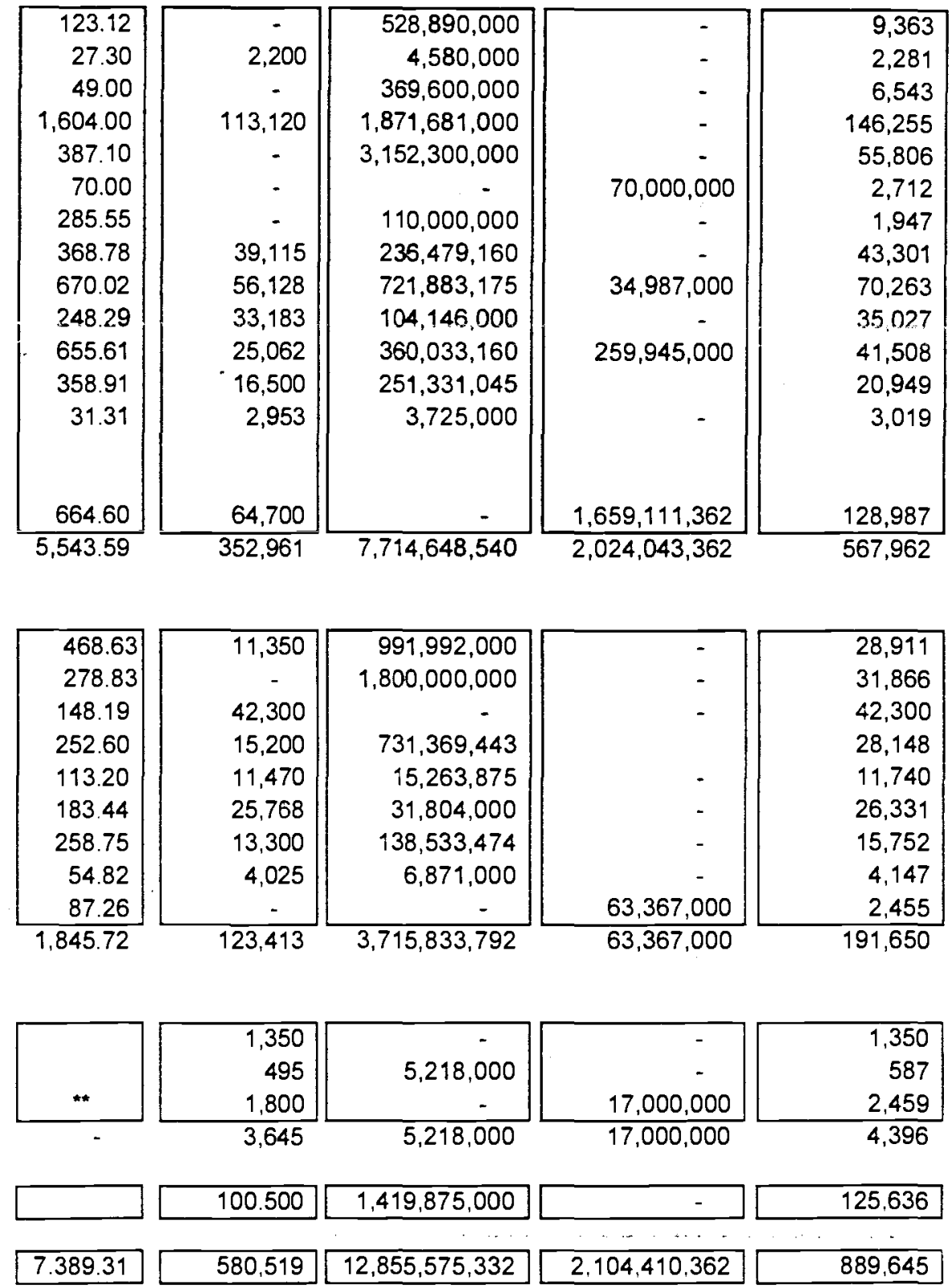

" US $\$ 1,800.00$ were paid by Mr. Hazel for transportation of WFP pickup from panjao to Yakawlang \& Afs. 17,000,000 were paid as advance for the transportation of 16. M.T. of wheat fom panjao to Takht and for 8 M.T. of potatoes from waras to sarab

\section{Purchase of potatoes.}

Purchased in Bamyan

Purchased in Yakawlang

Purchased in Yakawlang*

Purchased by Hazel in Waras

Purchased by Ali in Wardak

\begin{tabular}{|r|}
\hline M.T. \\
\hline $2,277.04$ \\
$2,155.55$ \\
45.93 \\
4.91 \\
664.60 \\
\hline 5.148 .03
\end{tabular}

$5,148.03$

\begin{tabular}{|c|c|}
\hline US \$ & Mazar Afs. \\
\hline - & $4,032,000,000$ \\
\hline 140,636 & $1,485,304,450$ \\
\hline 2,400 & $40,860,000$ \\
\hline - & - \\
\hline 31,500 & - \\
\hline
\end{tabular}

$5,558,164,450$

\begin{tabular}{|c|}
\hline Kabul Afs. \\
\hline $2,863,380,000$ \\
$18,750,000$ \\
- \\
$10,515,000$ \\
$602,604,973$ \\
\hline $3,495,249,973$
\end{tabular}

Equivalent USS

\begin{tabular}{|r|}
\hline 182,329 \\
167,657 \\
3,123 \\
407 \\
54,850 \\
\hline 408,366
\end{tabular}




\begin{tabular}{|c|c|c|c|c|c|c|}
\hline & & M.T. & US $\mathbf{s}$ & Mazar Afs. & Kabul Afs. & Equivalent US\$ \\
\hline Purchase of wheat in Bamyan & * & 416.37 & 178,105 & 101,000 & - & 178,107 \\
\hline Purchase of wheat in Lal & \# & 100.00 & 1,300 & - & $687,933,000$ & 27,956 \\
\hline
\end{tabular}

- The amount represents the payment against the purchases in Bamyan.

* The amount represents the payment against the purchase of 100. M.T. of wheat. Purchased by Mr. Asif Ikram in Lal and distributed in Lal and surrounding areas.

\section{Wages.}

The amount represents the the wages paid in Bamyan, Yakawiang, Waras, La \& Panjao to temporary staff for survey, cleaning of the roads and for the purchasing $\&$ and distribution of food.

\begin{tabular}{|c|c|c|c|}
\hline US \$ & Mazar Afs. & Kabul Afs. & Equivalent US\$ \\
\hline- & $332.140,000$ & $17,550,000$ & 6,560 \\
\hline - & $4 E .100,000$ & $18,200,000$ & 1,521 \\
\hline 1,000 & $859,986,100$ & - & 16,224 \\
\hline - & $9 \subseteq .284,000$ & - & 1,758 \\
\hline - & & $132,120,000$ & 5,119 \\
\hline - & - & $5,300,000$ & 205 \\
\hline - & - & $73,478,000$ & 2,847 \\
\hline 1,000 & $1,33^{-}, 510,100$ & $246,648,000$ & 34,234 \\
\hline
\end{tabular}

\section{Rent of building.}

The amount was paid as six months' advance rent for WFP Yakawlang building from January 01, 1998 to June 30, 1998. to local shoora, whereas wharehouse in Yakawlang is free of charge.

10. Vehicle maintenance \& fuel.

The amount was spent for fuel and vehicle maintenance in Bamyan, Yakawlang, Waras, Lal \& Panjao .

\footnotetext{
Paid in Bamyan

Paid in Bamyan*

Paid in Yakawlang

Paid in Panjao \& Waras by Hazel

Paid in Lal by Asif Ikram

Paid in Panjao \& Wardak by Ali
}

US \$ Mazar Afs. Kabul Afs. Ea

\begin{tabular}{|c|c|c|c|}
\hline 600 & $775,230,000$ & - & 14,324 \\
\hline - & $16.271,000$ & - & 288 \\
\hline 5,937 & $158.379,500$ & - & 8,741 \\
\hline - & & $15,776,000$ & 611 \\
\hline - & - & $6,700,000$ & 260 \\
\hline 500 & - & $23,629,000$ & 1,416 \\
\hline 7,037 & $949.880,500$ & $46,105,000$ & 25,639 \\
\hline
\end{tabular}


11. Miscellaneous.

The amount was spent for Miscellaneous in Bamyan, Yakanlang, Waras, Lal, Panjao \& Wardak .

Paid in Barmyan

Paid in Yakawlang

Paid in Yakawlang*

Paid in Panjao \& Waras by Hazel

Paid in Lal by Asif Ikram

Paid in Paniao \& Wardak by Ali

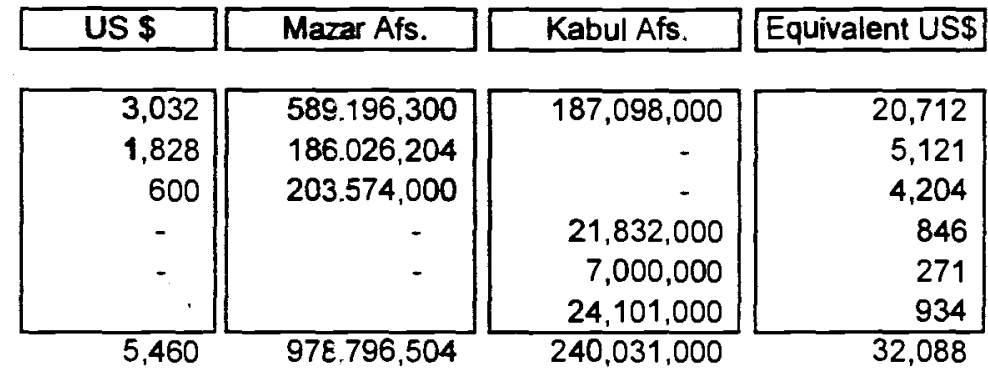

\section{Advances.}

The amounts were paid as advances to staff and transporters in Bamyan, Yakawlang, Waras, Panjao \& Wardak.

Aman
Gheyas
Akhter
Dost Mohammad
Razzaq
Qadeer
Haider
Mazar staff
Advance to Ali *
WFP Pul i khumri
WFP Pul i khumri *
Mission Advance*
Bahadoor
Hakim
Safderi
Jamil
Khan Ali
Nadir
Hassan Nabi
Khadim Hussain
M. Amir

13. Loan Repayments

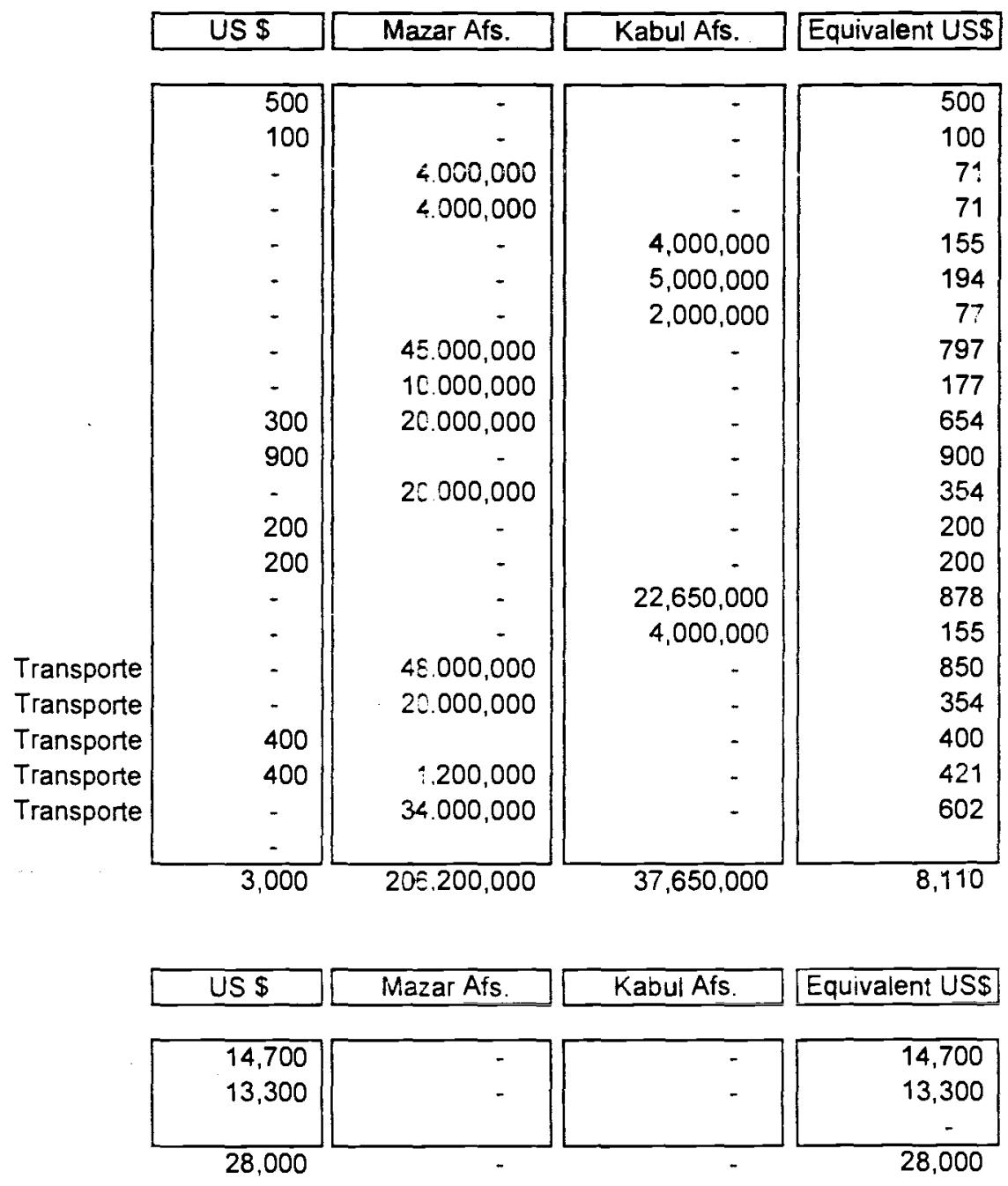

\section{Balance}

Repayed in Bamyam

Repayed in Yakawlang

Detail of cash balances in hand at different location with different payees is as follows

Cash in Bamyan

Cash in Yak. With Mr. Aziz

Cash with Mr. Hazel

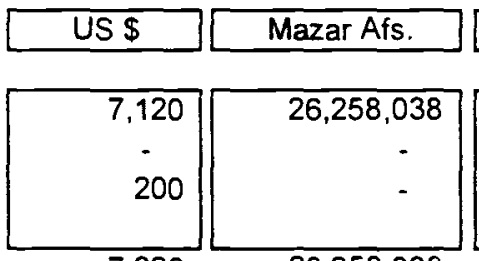

7,320

$26,258,038$
Kabul Afs.

Equivalent US\$

$11,243,165$
-
$(19,393,000)$

$(8,149,835)$

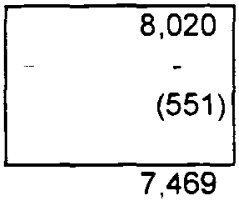




\section{MINUTES OF THE MEETING OF LOCAL PURCHASING COMMITEE}

Time and Date of Meeting : 09:00 A.M., 08 November 1997

Venue

: WFP Bamyan office

Participants

:1. Mr. Fayyaz Shah - Presiding. WFP Bamynan

2. Mr. Lal Mulepaty- Member, WFP Bamyan

3. Eng. K.B. Hazel - Member/Rapporteur,WFP Yak.

4. Eng. Muslim - Member, Shohada NGO Rep.

5. Eng. Younis - Member, Local Authorities Rep.

Highlights of the Meeting:

1. The Meeting was convened by WFP Yakawlang to discuss the possibility of purchasing surplus potatoes from the poor and small-scale farmers/small landholders in Bamyan, Yakawlang, Panjao and in Wardak who have surplus potatoes for subsequent distribution amongst vulnerable persons in the districts of Bamyan, Yakawlang, Lal, Panjao and Waras.

2. The Committee during the course of discussions decided to buy surplus potatoes from the small-scale farmers/ small landholders who have sufficient stocks of potatoes for family consumption as well as seeds for the next cropping season thereby stretching the cash benefits amongst them rather to individual suppliers and traders.

3. The prevailing price of potates in the local markets at Mazari Afs 30,000 per seer $(7 \mathrm{~kg}$ ) which is equivalent to US\$78/MT* was agreed by the Committee as the standard purchasing price of WFP during the emergency operations.

4. The Committee also agreed that standardized purchasing coupons and other reporting formats be followed strictly by WFP Teams in Bamyan, Yakawlang, Panjao. Lal and W'aras. Purchasing Teams will be authorized to issue potato purchasing agreements with the poor small-scale farmers/small landholders in different villages which will serve as references'supporting documents for processing payments which will be

handled separately by the WFP Accountant.

5. The Committee members were shown the samples of coupons/purchase contracts during the Meeting.

The Meeting was adjourned at 10:15 A.M.

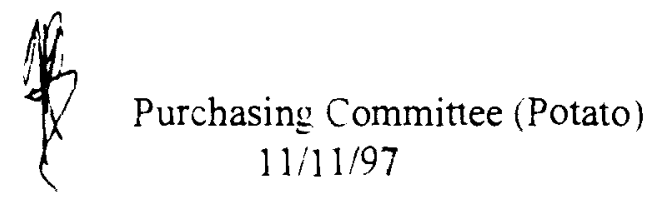




\section{LOCAL PURCHASE OF POTATOES -AFG PRO 5086/04}

The executing WFP office : WFP Bamyan/AFG

Responsible Officers $\quad$ : Ben Martinson, Pete Amolat, Fayyaz Shah

Members of field purchasing

committee

: 1. Fayyaz Shah - WFP Bamyan

2. Lal Mulepati - WFP Bamyan (alternate)

3. Ben Martinson - WFP Yakawlang

4. Pete Amolat - WFP Yakawlang

5. K.B. Hazel - WFP Yakawlang

6. Eng. M. Ali - WFP Yakawlang (for Wardak)

7. Eng. Muslim - Shuhada Ogganization (NGO)

8. Eng. Younis /Local Authorities

9. Seven farmers representing community

10. NGOs: OXFAM, NIDA,BCL,CCA (Yakawlang)

Date of Committee Meeting :08 November 1997

Commodity specifications : Locally produced potatoes corsidered surplus due to marketing constraints. in good conditions.

Quantity to be purchased : 6,500 MT potatces

Price offered and agreed : Mazari Afs $30.000 /$ seer (US\$ $-8 \mathrm{MT}^{*}$ )

Places of delivery $\quad$ : Bamyan, Yakawlang and Siahak/Behsud (Wardak)

Delivery period $\quad:$ From $11 / 11 / 97$ to $31 / 01 / 98$

Background and justifications for direct contracting:

The spectre of hunger and starration amongst 160,000 vulnerable persons in the Hazarajat areas of Afghanistan owing to the Taliban blockade and harsh winter conditions prompted WFP Afghanistan to implement an emergency food assistance in Bamyan province as well as parts of Eastern Ghor. A target purchase of 7.000 MT locally produced potatoes was planned by WFP Afghanistan in early November 1997.

The Purchasing Committee decided to buy directly from poor farmers rather than from traders in order to stretch the cash benefits amongst farmers thereby injecting financial resources in the local economy during the emergency winter period. 


\section{- Page Two-}

The purchase of surplus potato was not intended to disrupt the local markets .It was aimed to help poor farmers derive some income from their unsold crops and at the same time to help vulnerable persons during the critical period through food aid.

Modalities of local purchase and distribution and Payment:

1. A committee consisting of representatives of UFP, NGOs, community leaders and local authorities went around all potato growing villages in Bamyan, Yakawlang and Siahak (Wardak) to identif: and register farmers on following conditions:

i) Small-scale farmers landholders with moderate surplus of potatoes

ii) Should have sufficient stock of potatoes for family consumption as well as seeds for the next cropping season.

2. Over 900 farmers and their representatives were identified and registered in the potato growing villages of Bamyan. Yakawlang and Siahak (Wardak) during the emergency operations.

3. Buying price per seer $(7 \mathrm{~kg})$ of potato was discussed with farmers, village elders and with the local authorities on the basis of prevailing price of potato in the local markets on 11 th November 1997 was at Mazari Afs 30,000 per seer $(7 \mathrm{~kg})$ or at US\$78* per metric tonne . Farmers Committe was organized by the farmers themselves during the discussion/negotiation phase. This particular committee determined the consensus amongst farmers on the selling price of surplus potatoes to UFP. The above-mentioned price for potatoes established by the farmers " committee was accepted by all farmers in all potato growing villages remained constrant throughout the purchasing periiod.

Farmers greatly appreciated WFP's intervention with market rates at their door steps.

4. Purchasing Team of WFP visited each registered potato farmer and conducted inspection and weighments of surplus potato. After weighments, the WFP Purchasing Team entered into a purchase contract in two copies with the concerned farmer. One copy is retained by the farmer for presentation to the WFP. Accountant during payment. Another copy is retained by the WFP Accountant . Empty gunny bags with WFP markings were then issued to the concerned potato farmer with clear understanding that WFP Logistics Team would collect the purchased potatoes at a later date.

5. WFP's Logistics Teams collected the purchased potatoes from the concerned farmers on the basis of purchase contracts. The potatoes packed in WFP marked gunny bags were loaded to trucks for subsequent deliveries to various distributions sites of the Hazarajat.

6. WFP Distribution Teams distributed the purchased potatoes at various distribution sites in Bamyan, Yakawlang. Lal. Panjao and in Waras districts.

7. WFP Accountants processed payments of potatoes for farmers who sold their surplus potatoes to WFP after verification of purchased contracts and receipts records.

${ }^{*}$ Average exchange rate: US\$1.00 = Mazari Afs 54.945 .05 in Bamyan'Y'Yakawlang markets. 
1

as

POEAPOE CONTRACT HOLDEN PAKAWLANG

17

$2 x=2711$

Contract For The Sale Of Potato

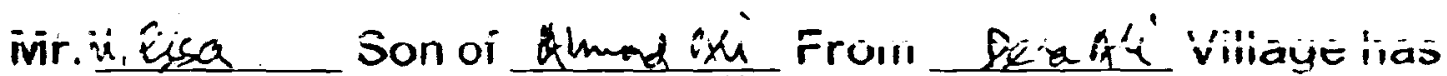
agreed to sell gook seer ( 6) So MT) of potatoes to W'FP at the rate of 30,000 AFS/Seer or seven KG.

MrNésa should be paid an amount of AFS 27, no, no/ oo after he has completed supplying the above amount

$\therefore$ Signature o? conítazior.

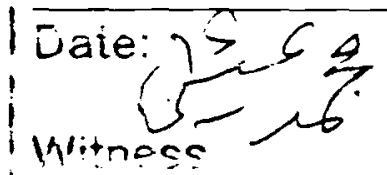

Signature of Representative Ate Qu er z tie: $\frac{1}{4-12-9}$ Witness

D̃aie:
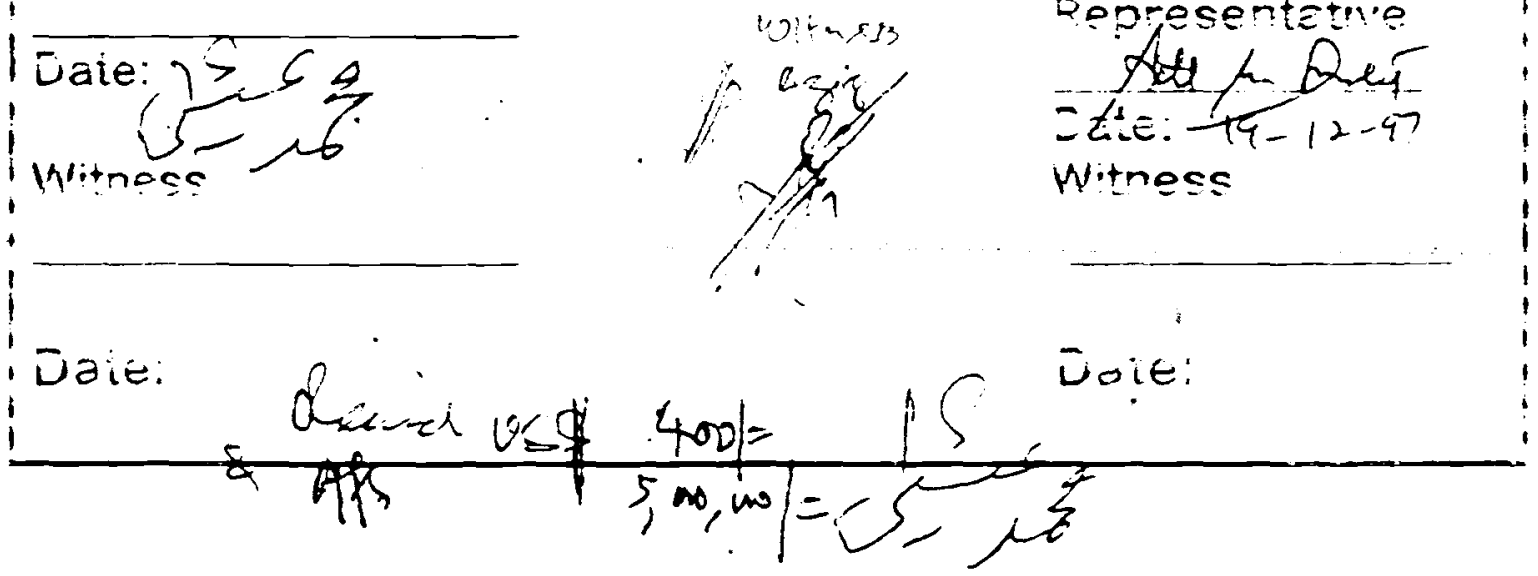


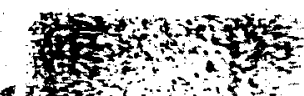

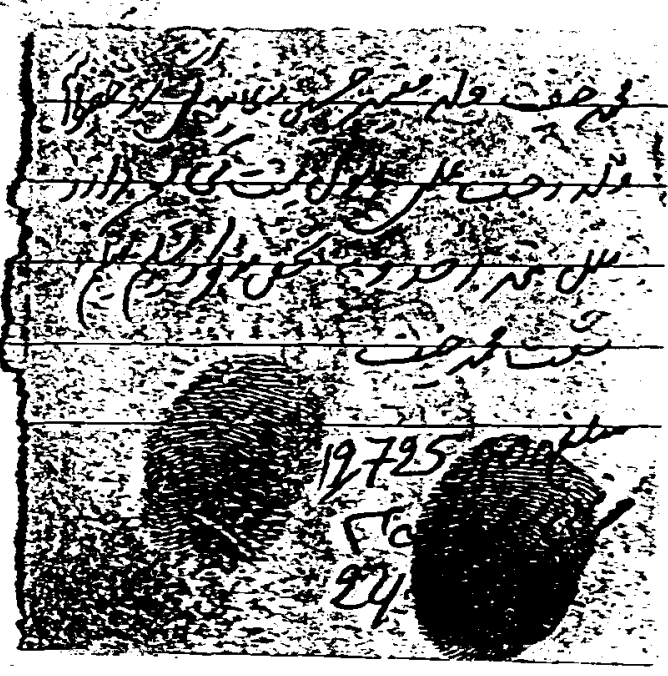

Qetementee at the backside

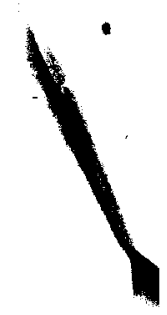

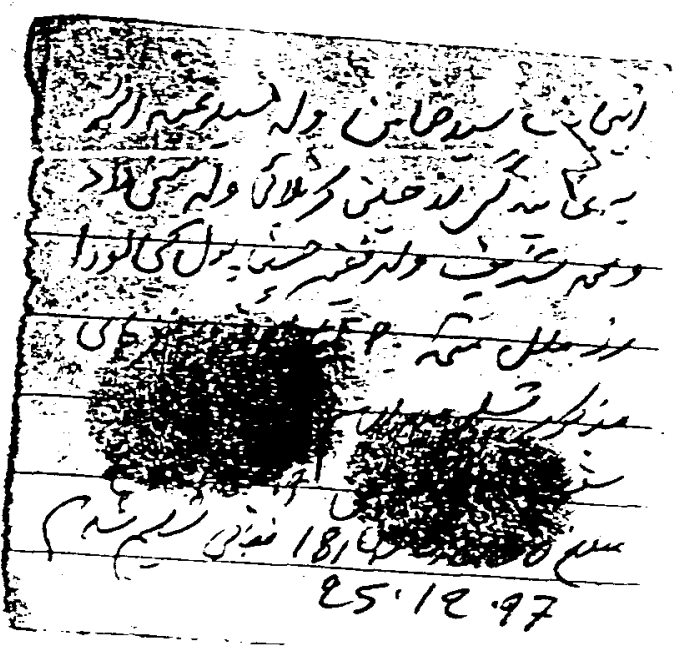

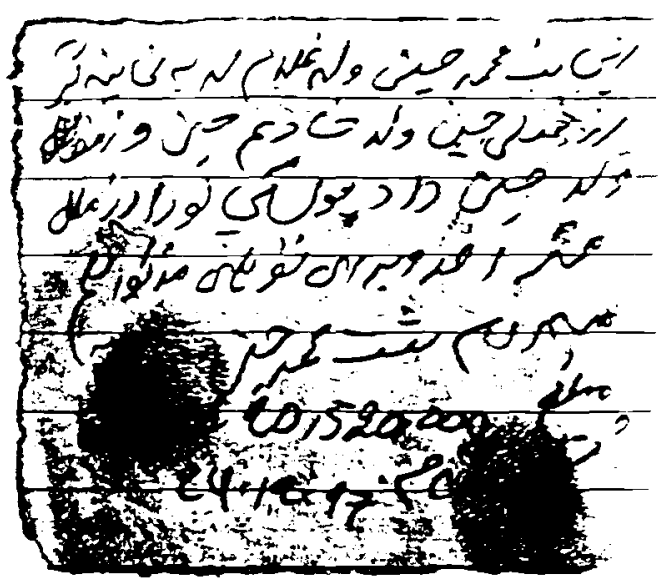




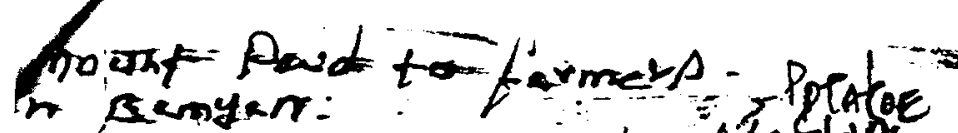

in semyar: Noplatos

$\therefore a r i 5 a m a$

310 - Safar
villeges Sorkhdar

Autiser) -600-

cost/ser-30,000

total cost $18,000,000=$

Date - 28,11, 97

singuature

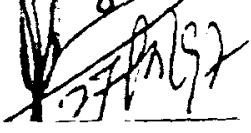

same Mirza. Moh Nergo

SlO Hidar

villeges Sorkhdaw

Ant (ser)-100-

cost / ser 30,000 -

total cost-3000,000-

Date $28,11,97$

sling nature

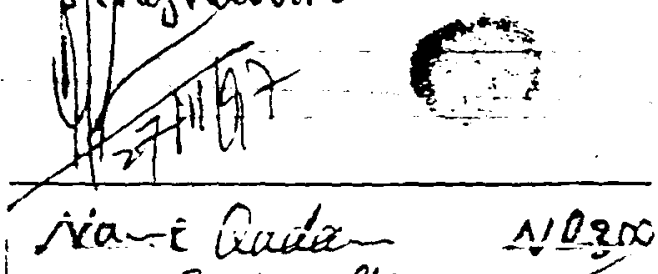

s10 Gurban Ali

villeges-Sorkhdew

Amtiser -200 -

cost $/ \sec 30,000$

$\left\{\begin{array}{l}\text { tatutrost-6,000, } \\ \text { Dote } 28,11, \\ \text { s) fuature }\end{array}\right.$

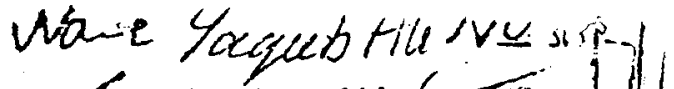

sto Moh. Hil

villeges so rkhida

- Amtrsevi-1000

cost $/$ ser $-30,000$

total cost-30,000,000

Date 28-11-97

singuatuve

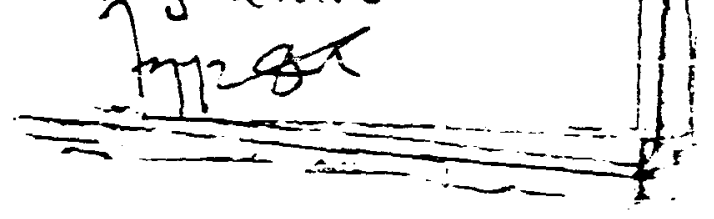

- No yoo

Name Abratitu-

Slo Mitussain

Wilige Nauabad taibti ifint Ssed) (loocser)

cost/ser - 30000/

to to $/ \cos t-30,000,00 \%$

Date 30-11-97

to: Panjab intas

singrature ing

77pst

in A AB tizeim

ir Aboulak

wilges syed thoel

$1 \% 386$

1. r $1901-2000$ -

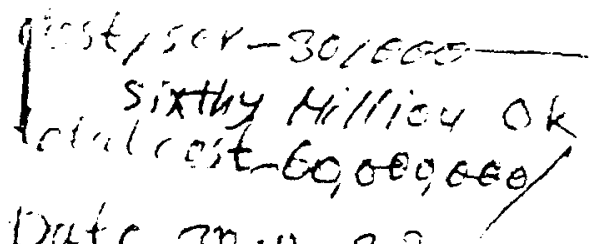

Dutc $30,11,8=$

sigudtive

7712 
LOCAL PLIRCHASE OF WHEAT AT PULIKUMRI-ATU PRU 5086/04

The execuling WFP office : WFP Bamyan' AFG

Responsible otficer

: Angur Froser/Logistics Ofiver

Members of field Purchasing

Comuniuce

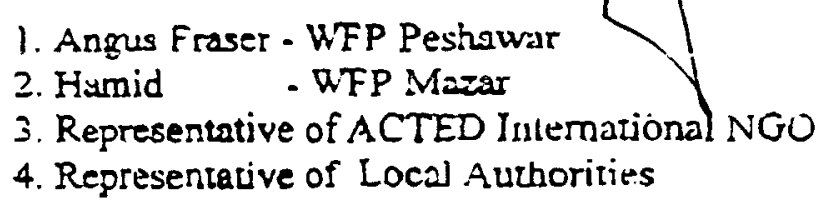

Dare of Commirtee Meeting : 11 November 1997

Commodity specificarions : Locally produced wheat is Baghlan piovince in good condition and in $100 \mathrm{~kg}$ bags

Amount in be purchased $\quad: 400 \mathrm{MT}$ locil wheat

Price of wheat : US\$400/MT delivered in Bamyan from Pullkumri, Baghlar: province

Delivery Place : Bamyen

Delivery period $\quad: 11 / 11 / 97-31101 / 98$

Background and justificarion for direct contracting:

WFP Afghanistan implemented the Bamyan EMOP starting in early November 1997 to prevent hunger and starvation amongst 160.000 vilnerable persons who were affected by the Tuliban biockade, rampant inflation and the harsh winter. As cerenls were in shon, supply in Bamy an and the rest of the Hazarajat areas, efforts were mude by WFP A Eghanistan io find and purchase surplus wheat in the adjacent provinues for deliveries to Bumyan province. Mr. Angus Fraser visited Bughlan province for this purpose where he identified over $400 \mathrm{MT}$ of locally produced wheat and negotiatcd with tianspurt conuactors willing to deliver the locally purchased wheat to Bunyan province.

Modalities of lucal purshase of wheat in Baghlan province:

1. The Purchasing Cummince in Baghlan decided to enter isstu clirect purchase contracts with severil wheat farmers ufter finding dvailahility of over $100 \mathrm{MI}$ 



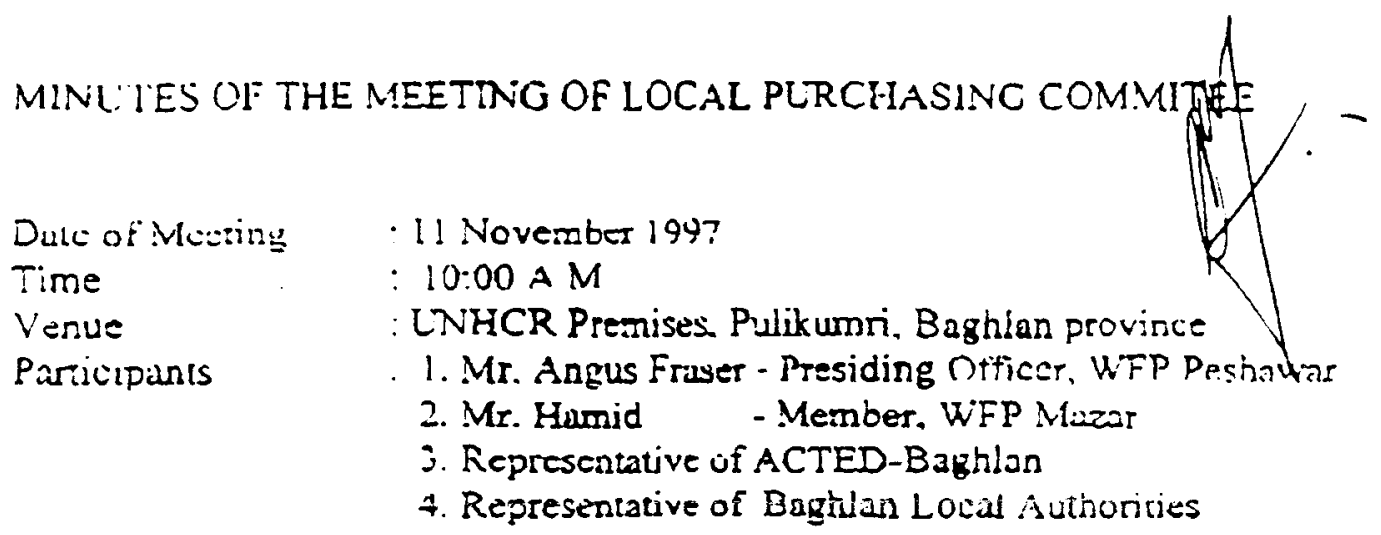

Highlights of the Meeting:

The Purchasing Conunite was cunvened on 11 th November 1997 in order to discuss the possibility of purchasing over $400 \mathrm{MT}$ wheat from the farming commurizic. of Baghlan province and deliver the grains to food deficient Bunyan province. The locally produced whear was ennsidered as supplus due to lack of purchasing power amongst the population and the high tansport costs of cxporting the commodity to neivibosing puvinges. The Meeling also reviewed the fond and ranspor costs invoive which would be at L'SStUV/MI wheat upon delivery in Bamyan.

During the rourse of deliberation. the Commutee agreed in behalt of WFP to purchase up to t00 MT locally produced wheat at the prevailing matkets tates of Bumyal Yaldwlang: which stood at L'S\$00MT upon delivery in Bamyan.

The Commiree also authorized Mr. Angus Fraser to finalize the A grtement with the concerned Coneraitors.

The Meeting was adjouned at 1::00 A.M.

Purchosing Commitee, Baghlan

is!11197 


\section{MRTTES OF THE MEETING OF LOCAL PURCHASING COMMITTEE}

Time and Date : 14:00 Hrs; December 4, 1998

Venue

: WFP Jakawlang

Participants $\quad: 1$. Mr. Ben Martinson, Presiding Officer. WFP Yakawlang

2. Mr. Pete B. Amolat, Member Rapporieur, WFP Yakawlang

3. Mr. Asif Ikram , Member, WFP Yakawlang

4. En@.K.B. Hazel , Member. WFP Yakawlang

5. Mr. Jaffer Khan , Member. Local Authorities

6. Dr. Aman , Member. OXFAM Yaḱ./Lai

Meeting Highlights:

1. The Meeting was convened at WFP Yakawlang office to explore the possibility of purchasing $200 \mathrm{MT}$ wheat made available in Lal, Eastern Ghor which local authorities considered surplus in view of the lack of purchasing power amongst the population. The subject wheat was brought into Lal from the neighboring district of Daresuf, Samangan prorince sometime in Seftember/October 1997 before the closure of access routes by the heary snowfalls.

2. The Meeting was informed that $200 \mathrm{MT}$ wheat made available in Lal was being offered by some farmers to WFP at the prevailing local marketprice of Kabuli Afs 50.000 per seer $(\mathrm{k} g)$ which was equivalent to US $\$ 1.94$ per seer.

3. In riew of the non-availability of wheat in large quantities in Yakawlang and Bamyan and considering that the purchase involved would not disrupi the local markets in Lal in view of the lack of purchasing power amongst the population. the Purchase Comnittee agreed to purchase initially 100 MT wheat from the representative of the farmers at the price of Kabuli Afs 50.006 per seer upon delivery of wheat in Lal Centre.

4. The Committee authorized Mr. Asif Ikran to issue coupons/receipts of deliveries upon receipt of $100 \mathrm{MT}$ wheat from the farmers' representative in Lal. Mr. Ikram was advised to report the transactions to WFP Yakawlang/Bamyan and request Mr. Martinson to deliver the cash requirements upon receipt of the wheat in $\mathrm{Lal}$.

5. Meeting also discussed other modalities of the purchase. e.g. check weighments. reporting formats and parment procedures.

The meeting was adjourned at 3:15 P.M.

Local Purchase Committee for Lal Wheat

07/12/97 


\section{LOCAL PURCHASE OF WHEAT AFG PRO 5086/04}

The executing WFP office: WFP Yakawlang/AFG

Responsible officers $\quad$ : Ben Martinson, Pete B. Amolat

Members of field

Purchasing Committee $\quad$ : 1. Ben Martinson - WFP Yakawlang

2. Pete B. Amolat- WFP Yakawlang

3. K.B. Hazel - WFP Yakawlang

4. Asif Ikram - WFP Yakawlang

5. Oxfam Lal (Eastern Ghor) Representative

6. Shura Representative of Lal (Eastern Ghor)

Date of Committee Meating: 04 December 1997

Commodity specification : Surplus locally available wheat from Ghor province in good clean condition, in gunny bags (each bag with an average of $100 \mathrm{~kg}$ wheat.

Quantity of wheat to be

locally purchased in Lal distt: 200 Metric Tonnes

Price of Wheat

Place of Delivery

Delivery period
: Kabuli Afs 50,000/seer (7 kg) or US\$357.15* per MT

: Centre of Lal district (Ghor province)/AFG

$: 06 / 12 / 97-07 / 01 / 98$

Background and Justifications for direct contracting:

The vulnerable population in the eastern area of Ghor province. where Lal district is situated. has been affected by the road blockade exacerbated by rampant inflation and the harsh winter. WFP Afghanistan decided to provide emergency food assistance to this part of Ghor province in early November 1997 in order to prevent starvation and hunger.

When WFP conducted a survey on food availability and food prices in early November 1997 at the Yakawlang markets. it was found that only 20 metric tonnes of wheat were available at the price of Mazari Afs 150.000 per seer $(7 \mathrm{~kg})$ or at US\$2.66 per seer. WFP decided not to buy the available wheat in Yakawlang at that time because the quantity was limited and WFP thought the move could disrupt the local markets.

* Average Exchange Rate : US1.00 = Kabuli Afs 25.808 in local markets (Taliban). 


\section{- Page 2 -}

The Local Shura (Council) of Lal has informed WFP Mission in early November 1997 about the availability of 200 MT of surplus wheat in Lal. Eastern Ghor which was brought to Lal from the neighbouring Daresuf district of Samangan province in September/October 1997 before the blockade by snowfall.

The Purchasing Committee decided to purchase $200 \mathrm{MT}$ of surplus of wheat made available in Lal district, Ghor province, Afghanistan based on the strong recommendations of the local authorities and the joint WFP-OXFAM Team in Lal district who confirmed feasibility/availability of the wheat at reasonable costs. As per adrice from the WFP AFG Country Office, an initial purchase of 100 MT wheat was decided by the Comittee with the understanding that additional $100 \mathrm{MT}$ wheat could be later on recommended for purchase, if feasible.

The price of locally available wheat in Lal district at Kabuli Afs 50,000 per seer which was equivalent to US\$1.94* per seer in December 1997 was accepted by the Purchasing Committee taking into consideration the costs of transport and nonavailability in large quantities of wheat in Yakawlang and in Bamyan.

Modalities of Local Wheat Purchase and Distribution:

1. The Purchasing Committee surveved the local wheat markets in Lal and found that the $200 \mathrm{MT}$ of wheat was available at reasonable costs and that the farmers-sellers assured the delivery of wheat. if purchased. There was consensus amongst Committee Members that the local purchase would not cause negative effects on the local markets of Lal district due to lack of purchasing power amongst the populatioin.

2. Sellers representative was nominated by the sellers who agreed on the terms and conditions in the presence of the Lal Shura and the Committee. Wheat grains were inspected and checked weighments of wheat bags which conformed to the specifications of the Purchase Committee.

3. After inspection and check weighments of wheat. the Committee entered into agreement with the sellers representative. After the agreements, WFP Distribution Team at Lal Centre received $100 \mathrm{MT}$ local wheat from the sellers' representative at different dates for which coupons and suitable records were established on the transactions.

Modalities of Payment of wheat:

When informed by W'FP EMOP in Lal about the deliveries of wheat as agreed by the Purchasing Committee and the Sellers' Representative. WFP Yakawlang Team consisting of Messrs. Ben Martinson and Pete Amolat went to Lal twice and delivered the cash payments for the wheat. Receipts of payments were obtained from the sellers" *Average exchanged rate: US $\$ 1.00=$ Kabuli Afs 25.808 at local markets(Taliban). 
representative after verification of coupons and delivery receipts.

Distribution of Wheat to Bonafide Beneficiaries in Lal district:

The 100 MT locally purchased wheat was distributed to vulnerable persons of Lal district by the WFP Distribution Teanis following the cstablished procedures.

Due to the worsening winter conditions, the WFP Purchasing and Distribution Teams in Lal were pulled out from Eastern Ghor to Yakawlang for safety reasons. The remaining $100 \mathrm{MT}$ wheat available in Lal prior to the pull out of WFP Teams was not purchased by WFP. 
EMOP Bamyan in Yakawlang/AFG

05 December 1997

Haji Mohammed Raza

Farmers Representative

Lal. Eastern Ghor province. Afghanistan

Dear Haji Mohammed Raza.

Subject: Purchase of. 100 Metric Tonnes of Wheat in Lal. Eastern Ghor.AFG

This has reference to your meeting with the WFP Local Purchasing Committee on 04 December 1997 in respect to WFP"s plan to purchase surplus wheat made available in Lal district which will be subsequently distributed to target beneficiaries amongst the vulnerable population in the district during the winter.

The Purchasing Committee. during its meeting on 4th December 1997. has been informed that the $100 \mathrm{MT}$ wheat, which was brought into Lal district Lal from the neighboring Samangan sometime in September/October 1997 before the closure of access routes by heary snowfalls. is available for purchase by WFP at the prevailing market price of Kabuli $A f_{5} 50.000$ per seer $(7 \mathrm{~kg})$. The intended purchase will not disrupt the local markets in view of the lack of purchasing power of the local population.

We are pleased to inform you of WFP's decision to go ahead with the local purchase of $100 \mathrm{MT}$ wheat at the price of Kabuli Afs 50.000 per seer $(7 \mathrm{~kg})$ from Lal district. We understand that you have been selected by the concemed farmers as their authorized representative who could ensure the deliveries of the wheat to Mr. Asif Ihram. Team Leader of WFP EMOP Team in Lal. Eastern Ghor.

You are hereby requested to contact Mr. Asif Ikram (WFP Reprentative) who is currently at the OXF.AM-Lal office for the arrangement of deliveries. Kindly be guided on the following terms and reference of the local purchase:

1. Wheat should be cleaned and of good quality.

2. Wheat should be packed in gunny bags with average weight of $100 \mathrm{~kg}$ 'bag.

3. Wheat should be delivered to WFP at Lal Centre. Eastern Ghor province at your own transport arrangements.

4. Wheat deliveries should be done between 06 December 1997 and 07 Jan. 1998.

5. Checked weighments of wheat delivered will be undertaken by WFP.

6. UFP reserves the right to reject wheat which do not conformed to quality standard and bags that are underweight.

7. UFP will pay upon verification of records. e.g. receipts and deliveries. the price of wheat at prevailing market rate of Kabuli Afs 50.000 per seer $(7 \mathrm{~kg})$. Payment will be made by WFP in Lal Centre. Eastern Ghor. 


\section{- Page Two -}

Kindly contact UFP Yakawlang through Mr. Asif Ihram, EMOP Team in Lal, should you have any objection to the aforementioned terms and conditions of WFP's intended purcase of $100 \mathrm{MT}$ wheat in Lal district through your representation.

We look forward to a smooth and successful deliveries of wheat to WFP in the nearest future. Thank you in advance, for your kind collaboration.

Yours sincerely,

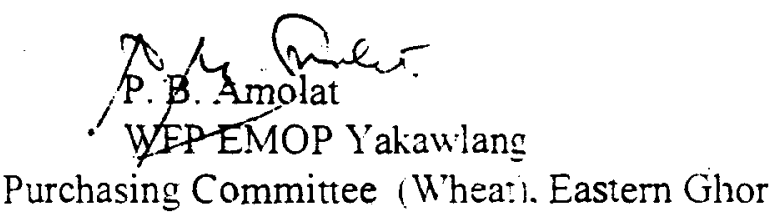

cc: Mr. Anis Haider. CD. UFP Afghanistan (in Islamabad)

cc: Mr. Tarek Elguindi. DCD. W'FP Afghanistan (in Islamabad),

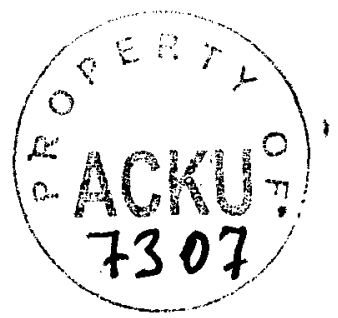

